\title{
Enhancing Voter Education Knowledge of Adolescents Through Social Interaction Instructional Models
}

\author{
Grace Ogechukwu Ugwonna ${ }^{1}$, Samuel Agozie Ezeudu ${ }^{1}$, Okechukwu Onyinye Nwaubani ${ }^{1}$, \\ Patricia Nwamaka Aroh ${ }^{1}$, Luke Chizoba Ezema ${ }^{1}$, Samuel Okechukwu Ome ${ }^{1}$, Anthonia N. Utoh-Ofong ${ }^{2}$, \\ Ogochukwu Stella Okafor ${ }^{3}$, Obiageli Calista Onyeanusi ${ }^{1}$, Lazarus Bassey Abonor ${ }^{4}$ \& Edith N. Nwokenna ${ }^{5}$ \\ ${ }^{1}$ Department of Social Science Education, University of Nigeria, Nsukka, Enugu, Nigeria \\ ${ }^{2}$ Quality Assurance Dept National Examinations Council (NECO), Minna, Niger State, Nigeria \\ ${ }^{3}$ Department of Arts and Social Science Education, St. Augustine College of Education Project (T.I.M.E) Akoka \\ Lagos \\ ${ }^{4}$ Department of Social Work, University of Calabar, Cross River State, Nigeria \\ ${ }^{5}$ Department of Arts Education, University of Nigeria, Nsukka, Enugu, Nigeria \\ Correspondence: Dr. Patricia Nwamaka Aroh, Department of Social Science Education, University of Nigeria, \\ Nsukka, Enugu, Nigeria. E-mail: nwamaka.aroh@unn.edu.ng
}

Received: February 20, 2019 Accepted: April 25, 2020 Online Published: May 8, 2020

doi:10.5539/gjhs.v12n5p139 URL: https://doi.org/10.5539/gjhs.v12n5p139

\begin{abstract}
The study determined the effects of group investigation and jurisprudential inquiry of social interaction instructional models on adolescents' knowledge of voter education related contents in senior secondary school Government curriculum. The ultimate aim was to curb voter apathy among young citizens. The design was Quasi-experimental non-equivalent pre-test, post-test control group design. The sample for the study consisted of 165 SS II students drawn from public secondary schools in Nsukka Local Government Area of Enugu state Nigeria. Using a multi-stage sampling technique, the intact classes from the schools were assigned to the two experimental groups. Data collected using Multiple Choice Government Achievement Test (MCGAT) were analyzed employing mean and standard deviation for the research questions and ANCOVA for testing the hypothesis at $\mathrm{P}<0.05$ level of significance. The findings showed that group investigation and jurisprudential inquiry models enhanced students' acquisition of knowledge in voter education related contents; although group investigation seemed more efficacious. There was also a statistical difference in the mean achievement scores of students with group investigation performing significantly better. These findings were exhaustively discussed with the far-reaching recommendations on how to improve voter education knowledge and potentials of young ones as future adult citizens.
\end{abstract}

Keywords: Voter apathy, Voter education, interactive instruction, adolescents, academic achievement, Government

\section{Introduction}

The incidence of low voter turnout in some democracies all over the world particularly in developing countries has remained a contentious issue to sustainable democracy and proper representation. The emergence of democracy in developing countries such as Nigeria was an aftermath of the decline of military rule and it is very sacrosanct in the right choices of the leaders by the people. Based on the right of eligible voters to perform their civic responsibility, one of which is choosing their leaders in elections, electoral commissions in Nigeria and elsewhere globally engage in awareness creation prior to general elections to enlighten the masses on the necessity of participating in electoral processes. It is expected that with proper awareness, citizens would perform their civic responsibilities (e.g voting in elections). Available evidence have shown a great decline in voter turnout between 1999 and 2015 in Nigeria. International Institute for Democracy and Electoral Assistance [IDEA], (2018), analysis succinctly revealed that there is a wide margin between the voting age population and the number of registered voters. Thus while the voting age population remained higher than the number of registered voters across the election years, the turnout equally does not reflect the number of registered voters as it continued to retrogress. This could be an indication that the future of democracy in Nigeria may be bleak. 
Studies have also shown that decline in voting is on increase among young ones (Blais \& Rubenson, 2013; Danielle \& Danielle, 2011; Smets 2012). This position suggests that perhaps this age bracket seem not to be acquiring adequate orientation and awareness on the essence of participation in electoral processes. Thus, lively discussions by several analytical studies reiterated that the most logical approach to active participation in political and electoral processes is effective dissemination of political contents at the school level (Journell, 2014; Ogujawa \& Udoh, 2015; Dag, Sozer, \& Sel, 2015). Similarly, Ohme, Marquart and Akristensen (2019) aligned with the views of other studies such as Eichhorn (2018), Keating and Janmaat (2016) that civic education could increase knowledge about political matters since adolescents have the propensity of more educational idea towards politics than adults (Keating \& Janmaat, 2016) through classroom discussion (Galston, 2007; Levy, Solomon, \& Collet-Gildard, 2016). This could be justified by the fact that education gives people the opportunity of empowerment and proper value orientation. Thus, it is not an only approach for encouraging participation but a fundamental paradigm shift for behavioural and attitudinal transformation. Therefore, democracy may not succeed unless citizens particularly young ones are educated to make wise political choices and decisions.

In view of the important role of education (via schools or other informal means) in upholding democratic values of the society especially in Nigeria, voter education related contents were incorporated into school subjects such as Government, with prescribed methods of teaching that are student-centred in nature. Prescribed instructional methods for effective teaching of Government include Discussion method, Fieldtrip, Inquiry, Debate etc (FME, 2007). Indeed, evidence shows that undue dependence on teacher-centred instructional methods tends to encourage passive learning among students (Nyamwembe, Ondig, \& Kiio, 2012; Journell, 2014). Further studies also established that although the teacher-centred method may be suitable for large classes and quick coverage of curriculum contents, it has been found ineffective for students' meaningful learning (Ubulom \& Ogwunte, 2017). This situation justifies the need for a paradigm shift from teacher-centred instructional methods (that allow teachers to dominate classroom activities, thereby discouraging students' active participation and interaction during classroom instruction) to learner-centred ones which encourage active participation and interaction of students in instructional activities and related experiences.

\subsection{Statement of the Problem}

The reoccurring voter apathy in elections in Nigeria between 1999 and 2015 particularly among young ones remains worrisome to the future of sustainable democracy. Considering the role of youths in sustaining democracy, efforts have been made to streamline electoral contents such as voter education related contents into the school curriculum to enable young ones to acquire necessary knowledge that will enable them to participate actively in the political system. In a bid to ensure effective assimilation of the contents, the Federal Ministry of Education in Nigeria (2007) prescribed student-centred instructional methods such as discussion, debate, inquiry methods among others for the teaching of the contents. Regrettably, studies have shown that teachers do not seem to employ the student-centred instructional strategies that encourage interaction, discussion and debate among students and between students and teachers in teaching political contents. This probably may be the reason for the persistent low performance of students in political-related contents as noted by the West African Examination Council (WAEC) Chief Examination's report over the years (2015-2017).

The poor performance of students was attributed to inappropriate instructional methods employed by teachers among other factors. This position, therefore, elucidates the rationale for this study. Furthermore, a large body of research has focused on the impact of civic education on political activities but not specifically on voter education contents of school curriculum using student-centred instructional strategies. Against this backdrop, the study sought to determine whether students' academic achievement in voter education related contents of Government curriculum could be enhanced using two social interaction instructional models, Group investigation and jurisprudential inquiry models.

\subsection{Instructional Models}

Given the constant emphasis on lifelong learning and the need for synergy between societal activities and the classroom learning experiences, it is imperative to adopt methods of instruction that give students the leverage of discussions and deliberations on societal issues while working in a group may improve better learning outcomes especially voter knowledge. Thelen (1960) developed models of instruction known as group investigation model while Oliver and Shaver (1966) also modelled instructional activities referred to as jurisprudential inquiry model. These models amidst other instructional models were categorized into a family of models by educational scholars such as Joyce and Weil (2000) and Joyce, Weil and Calhoun (2008) one of which is social interaction model.

The social interaction model is a model that reflects a view of human nature, which gives priority to social relations and the creation of a better society (Joyce \& Weil, 2000; Patel, 2013). It is regarded as a student-centred 
instructional strategy that facilitates group work, encourages interaction and meaningful dialogue among learners (Vacca, Vacca, \& Mraz, 2011; Hurst, Wallace, \& Nixon, 2013). Among the social interaction family are group investigation and jurisprudential inquiry models which could be referred to as debate method. Group investigation was propounded by Thelen following John Dewey's educational philosophy on democratic problem-solving. It is a model that encourages democratic classroom environment and enhances the development of skills for democratic participation through inter-personal social (group) skills (Joyce \& Weil, 2000; Siddiqui, 2013). This type of instruction constitutes four basic features which include investigation, interaction, interpretation and intrinsic motivation, compared with teacher-centred instruction, for internalization and enhanced knowledge (Lazarowitz, Hertz-lazarowitz, Khalil, \& Ron, 2013).

Application of group investigation model in the classroom requires the teacher to follow six stages which include; Grouping, Planning, Investigating, Organizing, Presenting and evaluating (Slavin, 1995). The first stage requires that students generate questions, after which the questions are sorted into categories. With the questions generated, the students then join the group of their interest. Secondly, a plan is made by the students on what to study and divide tasks among the individual member of the group. The third stage enables the students to seek for materials that provide answers to the questions raised by them in the group. Fourthly, the group determines the main idea in their findings and plan on how to present before the entire class. Evaluation is done after the presentation for the students to ascertain their performance in the group. These stages as pointed out by Sharan (1998) require that the teacher performs the role of a facilitator. The stages enable the learners to collaborate and interact thereby sharing ideas.

Jurisprudential inquiry model (JIM) as developed by Oliver and Shaver (1966) was basically designed to imbibe the jurisprudential frame of reference as a way of processing information and resolving social issues, emphasizes problem-solving technique that links knowledge and society and inculcate in students values and attitude via discussions, debates, and arguments over controversial issues, thereby developing citizens that are skilful in formulating social policy (Nwafor, 2014; Damanik, Degeng, Setyosari, \& Dasna, 2016; Toyosi \& Aminat, 2018). For effective application of JIM model in the classroom, the teacher follows the stages inherent in the model. These include orientation to the case, identifying the issues, taking positions, exploring the stance (patterns of argumentation), refining and qualifying the positions, and testing factual assumptions behind qualified positions (Achmad, Bundu, Suradi, \& Jufri, 2018; Joyce \& Weil, 2000a). Following the stages, the teacher first introduces the topic of discussion to the students and then arranges the students into teams with each team being assigned a side of the issue to represent in their respective group. Secondly, the students will work in their groups, gathering and analyzing facts about the issue. After gathering information, the students get back together as an intact class. At this point, the teacher will allow all of the teams representing the same side of the issue to get together to share information and prepare for the public discussion. Before the presentation, the teacher will select from the class those who will prepare questions to ask each of the presenters. Questions will also be asked to the selected members of the groups involved in the debate. The next stage is for the students to sit and debate on the issues. The teacher ensures that all views are respected, issues are thoroughly explored, and students clarify their arguments during a presentation in support of the side of the issue they represent (Nwafor, 2014). The knowledge acquired in this process could enable the students to lead or participate in activities in their communities such as participation in the electoral process (Bonnstetter \& Pedersen, 2009).

In view of the above, the objective of this study was to determine the effects of group investigation (GIM) and jurisprudential inquiry (JIM) instructional strategies, on students' acquisition of voter education knowledge related contents of senior secondary school Government in Enugu State, Nigeria. Thus, the research questions raised were: 1) What is the mean achievement scores of students taught voter education related contents in senior secondary school Government using group investigation model and those taught the same contents using the jurisprudential inquiry model? 2) Which of the models is more efficacious in enhancing students' achievement in voter education related contents in senior secondary school Government? The study equally assumed that there is no significant difference in the mean achievement scores of students taught voter education related contents of Government using group investigation model and jurisprudential model.

\section{Materials and Methods}

This study was a non-equivalent control group quasi-experiment. It was carried out in secondary schools located in Enugu state, Nigeria that offer voter education related contents. The population of the study consisted of adolescents in senior secondary school students 11 that offer Government subject. The adolescent students are potential voters that require knowledge of voter education. Intact classes participated in the study. The same intact classes participated in the pre-test and post-test. Thus, a sample of 165 students participated in the study. The 
cognitive ability of the students was determined through an instrument developed by the researchers, with 50 multiple-choice questions, in which only one option was the correct answer while one point value was given each question. Table of specification was developed by the researchers to ensure the spread of the question items to the different levels of the cognitive domain.

To carry out the experiment proper, two lesson plans were developed by the researchers based on each of the models, GIM and JIM. The lesson plans focused on voter education related contents as enshrined in the senior secondary school Government curriculum. These contents cover election, suffrage, electoral system, features of free and fair election and electoral commission. The lesson plans were the same in content but differ in feature as each was prepared following the stages of each of the models.

Regular teachers conducted the experiment after they were given thorough training by the researchers. This was in a bid to avoid the hawthorn effect. However, the researchers monitored the experiment for the effective implementation of the steps involved in the instructional strategies. Before the commencement of the experiment, the instrument was administered to the students as pre-test. Kuder Richardson formular (KR-20) test statistics was used to analyze the data collected and a reliability index of 0.79 was established. After completing the experiment, the same instrument was immediately re-administered to the students as post-test. The data collected were analyzed using SPSS version 20. Mean and standard deviation were used for measures of central tendency while the level of significance of $\mathrm{P}<0.05$ was adopted.

\section{Results}

Table 1. Mean and Standard Deviation of achievement scores of students taught voter education related contents using Group Investigation and Jurisprudential Inquiry models

\begin{tabular}{lllllllc}
\hline \multirow{2}{*}{ Variable } & \multicolumn{3}{c}{ Pretest } & & \multicolumn{2}{c}{ Posttest } \\
\cline { 2 - 3 } & $\mathrm{N}$ & Mean & SD & & Mean & SD & Mean Gain \\
\hline GIM & 87 & 16.42 & 4.52 & & 36.54 & 5.46 & 20.12 \\
JIM & 78 & 15.84 & 3.54 & & 31.76 & 4.58 & 15.92 \\
\hline
\end{tabular}

One hundred and sixty-five students participated in the study. The students taught voter education contents with GIM had pre-test mean achievement score of 16.42 with a standard deviation of 4.52 and posttest mean achievement score of 36.54 with a standard deviation of 5.46. Similarly, the students who were taught voter education related contents using jurisprudential Inquiry model had pre-test mean achievement score of 15.84 with a standard deviation of 3.54 and post-test mean achievement score of 31.76 with standard deviation of 4.58 . Mean gain scores of 20.12 and 15.92 for the students exposed to group investigation model and jurisprudential Inquiry model respectively shows that students exposed to group investigation model had higher post-test mean achievement than those exposed to jurisprudential Inquiry model. However, the result indicates that the two instructional models, GIM and JIM were effective as the mean achievement scores of the students in voter education related contents went from 16.42 and 15.84 in the pre-test to 36.54 and 31.76 for GIM and JIM in the post-test respectively.

Table 2. ANCOVA of the difference in the mean achievement scores of students taught using group investigation model and those taught the same content using the Jurisprudential Inquiry model

\begin{tabular}{lllllll}
\hline Source & Type III Sum of Squares & df & Mean Square & F & Sig. & Partial Eta Squared \\
\hline Corrected Model & $3035.953^{\mathrm{a}}$ & 2 & 1517.977 & 117.568 & .000 & .592 \\
Intercept & 3933.318 & 1 & 3933.318 & 304.637 & .000 & .653 \\
Pretest & 2099.796 & 1 & 2099.796 & 162.630 & .000 & .501 \\
Treatment & 743.532 & 1 & 743.532 & 57.587 & .000 & .262 \\
Error & 2091.659 & 162 & 12.911 & & & \\
Total & 199077.000 & 165 & & & & \\
Corrected Total & 5127.612 & 164 & & & & \\
\hline
\end{tabular}


Table 2 shows that the calculated value of F (57.587) for the effect of Group Investigation Model and Jurisprudential Inquiry model on students' achievement in voter education related contents had an associated probability value of 0.000 . Since the probability value of 0.000 is less than the 0.05 level of significance, the null hypothesis was rejected meaning that there is a significant difference in the mean achievement scores of students taught voter education related contents using Group Investigation Model and Jurisprudential Inquiry model in favour of students exposed to Group Investigation Model.

\section{Discussion}

The instructional strategies adopted in this study enabled students to enhance their knowledge in voter education related contents. The results presented in Table 1 revealed that for each of the groups (GIM and JIM), the post test achievement scores of students were greater than the pre-test mean achievement scores. This is an indication that the instructional treatment had a significant effect on the students. The findings further revealed that Group investigation model seems to have more effect on students' academic achievement in voter education related contents than jurisprudential inquiry model. While group investigation model encourages more interaction among group members, and also deals more on the collaborative efforts of the group members in finding solutions to problems, jurisprudential inquiry model, even though encourages interaction among members, seems more argumentative in structure. Hence, group investigation model may have given the students the opportunities of more interaction than jurisprudential inquiry model. The students' academic achievement improved using group investigation and jurisprudential models probably as a result of the features inherent in the models. Both models engage the learners in interaction, discussion, collaboration and investigating. Learning is facilitated because of the diverse input of the individual learners $\mathrm{n}$ their groups. The model considers the individual abilities of the learners thereby giving students the opportunity of impartation of knowledge and a launching pad for future independent decision making in electoral processes such as voting in elections.

The finding of this study corroborates the findings of Ohme, Marquart and Kristensen (2018) which found that civic education is important in youth political engagement. The findings of this study also aligns with Achmad, Bundu, Suradi and Jufri (2018);Adiansyah, Muh, Mansyur and Mu'nisa (2017) and Pitoyo, Waluyo and Suwandi (2014) which found group investigation efficacious. In addition, students are satisfied with GIM which makes them to work corroboratively. The findings of the study further coincides with the findings of Mehendale (2016); Farikah (2017); Yuliana, Sapri and Turdjai (2017) which found jurisprudential model efficacious instructional model although GIM proved more efficacious in this study. The findings of this study buttresses the views of Hackathorn, Solomon, Blankmeyer, Tennial and Garczynski (2011) which indicated that each teaching technique is effective for various levels of learning, but are dependent on the teachers' usage.

A study by (Borgonovi, D'Hombres, \& Hoskin, 2010) in Europe found that education is positively associated with voter turnout and information acquisition about politics. Another study conducted by Adiansyah, Muh, Mansyur and Mu'nisa (2017) showed that students' critical thinking skills improved with GIM than conventional method. A study conducted by Achmad et al., (2018) showed that the post test scores of students significantly improved after using GIM strategy in elementary class. Girsang (2014) found that GIM improved students' achievement in reading comprehension. Another study conducted by Farikah (2017) in Tidar University found that JIM motivated students in learning. Furthermore, a study by Yuliana, Sapri and Turdjai (2017) in PondokKelopa found that application of JIM improved social skills and achievement of students. Another study by Mehendale (2017) found that students participated actively with the use of JIM. GIM may have enhanced students' academic achievement more than JIM for the reason that it gives learners opportunities of more interaction in group learning than JIM.

The findings of this study lay credence on social development theory of Vygostky (1978) which postulated that social interaction plays a fundamental role in the development of the learners' cognition. Furthermore, the results of the study also confirms Dewey's theory of progressive education which states that learning takes place more when there is interaction among learners. Thus, the results obtained in the present study are in line with the literature concerning the improvement of students' achievement using student centred instructional strategies. However, preparation and execution of lesson activities using student centred strategies such as GIM and JIM could pose some challenges both for the teacher and the learners. It may present the teacher with the challenge of coordinating all the groups, ensuring that all the groups are properly guided for effective execution of the tasks presented to learners and for persistent active participation of all group members. Further studies in the area are suggested, to research on factors that could increase participation in political/ electoral processes. In this way, there could be sufficient turnout in voting for true reflection of people's preferences and for legitimization of government. 


\section{Conclusion}

Prior to this study, available evidence showed that teachers seem not to be engaging the students with students centred instructional strategies but rather focus on teacher centred instructional strategy. This may have led to students' poor achievement in voter education related contents of Government curriculum. Since evidence has shown persistent low turnout in elections in Nigeria especially among young ones, this study sought to determine how group investigation and jurisprudential inquiry of social interaction models could enhance academic achievement of secondary school students. Findings showed that both group investigation and jurisprudential inquiry models enhanced students' academic achievement although group investigation seems more efficacious in voter education related contents of Government curriculum.

This study contributes to the field of instructional strategies and electoral processes. First, the study show that student centred instructional strategies can have significant impact on how knowledge is assimilated, which is an indication that understanding of political contents can be enhanced using appropriate instructional strategies. Secondly, the findings suggest that with proper understanding of political contents, young ones can effectively participate in the electoral processes such as voting. In this way, the future of democracy in Nigeria and elsewhere globally can be assured. Thirdly, the finding creates more awareness on the extent to which voter apathy is increasing in democracies particularly among the young ones, which suggests huge challenges to the sustainability of democracy. The study therefore contributes to the body of knowledge on the essence of youth participation in electoral process, laying credence on the role of youths in sustaining democracy as the future adult citizens. Hence, if voter education related contents are properly taught using student-centred instructional strategies, knowledge gained in such instructional activities could be transmitted into real life experiences. This could be achieved by adequate and efficient monitoring of teaching and learning activities by stakeholders in schools management. Furthermore, youths are to be properly engaged in electoral matters while still in school through the formation of school clubs on voter education.

\section{Acknowledgements}

We thank the schools that participated in the experiment and the school administrators that permitted the researchers to carry out the research in their school. We particularly acknowledge the teachers of Government subject in those schools for playing the role of research assistants. We are also grateful for the assistance rendered by the data analyst. This research was self supported by the researchers; hence there was no grant for this study either in full or in part.

\section{Competing Interests Statement}

The authors declare that there are no competing or potential conflicts of interest.

\section{References}

Achmad, W. S., Bundu, P., Suradi, \& Jufri, M. (2018). Application of group investigation (gi) learning model in Pendidikanipssd course, to improve students' critical thinking skills. Journal of Research \& Method in Education (IOSR-JRME), 8 (2), 41-46. Retrieved from www.iosrjournals.org

Adiansyah, R., Mansyur, A. M., \& Munisa, A. (2017).The effectiveness of group investigation and scientific approach.Retrieved from https://www.researchgate.net/publication/321446997

Blais, A., \& Rubenson, D. (2013). The source of turnout decline: new values or new contexts? Comparative Political Studies, 46(1), 95-117. https://doi.org/10.1177/0010414012453032

Bonnstetter, R. J., \& Pederson, J. E. (2009). The jurisprudential inquiry model for STS. Retrieved from http://plato.acadiau.ca/courses/educ/GMacKinnon/Educ4143/graphics/Juris.\%20Inquiry\%20Model\%20for \%20STS\%20(chapter\%209).html

Borgonovi, F., D'Hombres, B., \& Hoskin, B. (2010). Voter turnout, information acquisition and education: evidence from 15 European countries. https://doi.org/10.2202/1935-1682.2463

Dag, N., Sozer, M. A., \& Sel, B. (2015). Political education in school. Educational Research and Reviews, 10(14),1881-1887. https://doi.org/10.5897/ERR2015.2330

Danielle, R., \& Daniela, C. (2011). The political participation of Africa's youth: turnout, partisanship and protest. Retrieved from https://www.files.ethz.ch/isn/134548/AfropaperNo136.pdf

Damanik, H., Nyoman, I. S., Setyosari, P., \& Dasna, W. (2016). The learning of civics education based on contextual teaching and learning (CTL). Retrieved from pasca.um.ac.id`conferences $>$ index.php>

Eichhorn, J. (2018). Mobilisation through early activation and School engagement. The Story from 
Scotland.Journal of Youth Studies. https://doi.org/10.1080/13676261.2018.1450968

Farikah (2017). The Effectiveness of jurisprudential inquiry learning model in developing the students' competence in writing analytical exposition texts. Theory and Practice in Language Studies, 7(11), 990-995. https://doi.org/10.17507/tpls.0711.07

Federal Ministry of Education. (2007). Senior secondary school government curriculum. Abuja:NERDC

Galston, W. A. (2007). Civic Knowledge, Civic Education, and Civic Engagement: A Summary of Recent Research. International Journal of Public Administration, 30(6-7), 623-642. dhttps://doi.org/10.1080/01900690701215888

Girsang, R. E. (2014). The effect of applying group investigation method on students' achievement in reading comprehension. Retrieved from https://jurnal.unimed.ac.id/2012/index.php/jelt/article/view/1366

Hackathorn, J., Solomon, E. D., \& Blankmeyer, K. L. (2011). Learning by doing: An empirical study of active teaching techniques. Journal of Effective Teaching, 11(2), 40-54. https://doi.org/10.1037/e683152011-599

Hurst, B., Wallace, R., \& Nixon, S. B. (2013). The impact of social interaction on student learning. Retrieved from https://scholarworks.wmich.edu > cgi

International Democracy and Electoral Assistance. (2019). Voter turnout by election type: presidential. Retrieved from https://www.idea.int/data-tools/country-view/231/40

Journell, W. (2014).Teaching politics in the U.S. history classroom.The History Teacher, 48 (1), 55-69. Retrieved from https://www.jstor.org > stable

Joyce, B., \& Weil, M. (2000a). Models of teaching. Boston: Allyn and Bacon

Joyce, B., \& Weil.M. (2000b). Models of Teaching and Learning; Where Do They Come From and How Are They Used? Retrieved from https://kinasevych.ca > 2009/02/18 > joyce-weil 2000-models-of-teaching-

Joyce, B., Weil, M., \& Calhoun, E. (2008). Models of teaching (8th ed.). Englewood Cliffs, NJ: Prentice-Hall.

Keating, A., \& Janmaat, J. G. (2016). Education through citizenship at School: Do School activities have a lasting impact on Youth political engagement? Parliamentary Affairs, 69, 409-429. https://doi.org/10.1093/pa/gsv017

Lazarowitz, R., Hertz-lazarowitz, R., Khalil, M., \&Ron, S. (2013).Designing cooperative learning in the science classroom: integrating the peer tutoring small investigation group (PTSIG) within the model of the six mirrors of the classroom model. Retrieved from https://files.eric.ed.gov/fulltext/ed567161.pdf

Levy, B. L. M., Solomon, B. G., \& Collet-Gildard, L. (2016). Fostering political interest among youth during the 2012 presidential election: Instructional opportunities and challenges in a swing state. Educational Researcher, 45(9), 483-495. https://doi.org/10.3102/0013189X16683402

Nwafor, C. (2014). Use of jurisprudential innovative approach in teaching basic science: an alternative to lecture method. International Researcher, 3(1), 63-67. Retrieved from https://www.researchgate.net/publication/281178754_use_of_jurisprudential_innovative_approach_in_teac hing_basic_science_an_alternative_to_lecture_method

Nwankwo, C. F., Okafor, J. P., \& Asuoha, G. C. (2017). Principal component analysis of factors determining voter abstention in South Eastern Nigeria. Retrieved from https://www.researchgate.net/publication/317008043_Principal_Component_Analysis_of_Factors_Determi ning_Voter_Abstention_in_South_Eastern_Nigeria

Ogujawa, A. I., \& Udoh, A. P. (2015). Strategies for improving the teaching and learning of government as a core-subject in senior secondary schools. International Journal of Educational Planning \& Administration, 5(1), 51-61. Retrieved from http://www.ripublication.com

Ohme, J.,Marquart,F.,\&Kristensen, L. M. (2019). School lessons, social media and political events in a get-out-the-vote campaign: successful drivers of political engagement among youth? Journal of Youth Studies. https://doi.org/10.1080/13676261.2019.1645311

Oliver, D. W., \& Shaver, J. (1966). Teaching pupil issue in the High School. Bostonma: Houghtonmiffin

Patel, B. H. (2013). Social interaction model. International Journal for Research in Education, 2(5), 30-32. Retrieved from https://raijmronlineresearch.files.wordpress.com/2017/07/8_30-32-bhavin-h-patel.pdf

Pitoyo, A., Waluyo, H. J., \& Suwandi, S. (2014). The effect of group investigation learning model, accelerated 
learning team and role playing on elementary school students' writing skills viewed from cognitive style. Journal of Education and Practice, 5(2). Retrieved from www.iiste.org

Siddiqui, M. H. (2013). Group investigation model of teaching: Enhanc\#ing learning level. Indian Journal of Research, 3.

Smets, K. (2012). A Widening Generational Divide? The age gap in voter turnout through time and space. Journal of Elections, Public Opinion \& Parties, 22(4), 407-430.https://doi.org/10.1080/17457289.2012.728221

Sharan, Y. (1998). Enriching the group and the investigation in the intercultural classroom. European Journal of Intercultural Studies, 9(2), 133-140. https://doi.org/10.1080/0952391980090203

Slavin, R. E. (1995).Cooperative Learning: Theory, Research, and Practice. Boston: Allyn\& Bacon

Toyosi, M. S., \& Aminat, A. (2018). Effects of jurisprudential inquiry model of instruction on performance and retention on ecological concepts among secondary II students in Nigeria. International Advanced Journal of Teaching \& Learning. Retrieved from https://www.zeetarz.com/iajtl/wp-content/uploads/2018/09/Effects-of-Jurisprudential-Inquiry-Model-of-Inst ruction-on-Performance-and-Retention-on-Ecological-Concepts-among-Secondary-II-Students-in-Nigeria.p df

Thelen, H. (1960). Education and Human Quest. New York: Harper \& Row Publishers Inc.

Ubulom, W.J ., \& Ogwunte, P. C. (2017). Evaluation of instructional resources for teaching business subjects in public secondary schools in Rivers State. Nigeria International Journal of Innovative Education Research, 5(4), 67-74. Retrieved from http://seahipaj.org/journals-ci/dec-2017/IJIER/full/IJIER-D-9-2017.pdf

Vacca, R. T., Vacca, J. L., \& Mraz, M. (2011). Content area reading: Literacy and learning across the curriculum (10th ed.). Boston: Pearson

WAEC e-learning. (2015). West African Examination Council. Retrieved from Waeconline.org.

WAEC. (2017). WAEC chief examiner's report. https://www.waecgh.org/Exams/ChiefExaminersReport.aspx

Yuliana, E., Sapri, J., \& Turdjai, T. (2017). The application of jurisprudential inquiry learning model to increase student's social skills and learning achievement. Retrieved from https://ejournal.unib.ac.id/index.php/diadik/article/view/3689

\section{Appendix}

\section{Appendix A}

\section{Multiple Choice Government Achievement Test (Mcgat) For Senior Secondary School II}

\section{PERSONAL DATA}

You are requested to give appropriate response to the questions.

Age:

Class:

School:

\section{INSTRUCTION:}

Time: 50mins

Circle the correct answers by choosing any of the options A, B, C, and D as considered most appropriate by you. The questions are in four options.

1. Elections are conducted to;
(A) provide permanent employment for the people
(B) make the people choose their leaders
(C) know the number of people in a country
(D) know the social amenities in the community 
2. Suffrage is also known as;
(A) Franchise
(B) Plebiscite
(C) public opinion
(D) Electoral college

3. For an election to be fair and free, the Federal Commission Must be;
(A) ready to manipulate result
(B) ready to reject criticisms
(C) headed by a minister in the executive
(D) independent of other institutions of government

4. Which of the following categories of people can vote in periodic elections?
(A) minor
(B) Aliens
(C) lunatics
(D) citizens

5. A 'Yes' or 'No' vote on a specific political issue in a country is called;
(A) referendum
(B) public opinion
(C) gerrymanding
(D) suffrage

6. The electoral system in which the winner should have more than all the votes of all other contestants put together is;
(A) simple majority system
(B) second ballot system
(C) referendum
(D) absolute majority system.

7. The following are the aims of election Except that;
(A) a group sticks on to power
(B) There is accountability of the leaders
(C) there is a smooth change of government
(D) The people determine who rules

8. Franchise means the right of all qualified citizens to;
(A) manipulate election results
(B) Conduct election
(C) enforce electoral laws
(D) vote and be voted for

9. In limited franchise, restriction on voting can be based on;
(A) height
(B) property
(C) Strength
(D) exposure

10. Which of the following is a limitation to universal adult suffrage? 

(A) wealth
(B) Tribe
(C) sex
(D) none of the above

11. Which of the following is an example of a general election?
(A) By-election
(B) Presidential election
(C) local election
(D) student union election

12. The purpose of election is to;
(A) allow people to participate in choosing their leaders
(B) Provide social amenities for the electorates
(C) give political education to the rich
(D) Allow the counting of votes in public

13. Universal adult suffrage is popular because it;
(A) allows for equal political representation
(B) allow for greater political participation
(C) encourages a multi-party system
(D) Ensures equal performance of all political system

14. Which of the following is not a factor that promotes democratic electoral system?
(A) Political consciousness
(B) periodic election
(C) up-to-date electoral register
(D) Popularity of the governor

15. A factor that could make elections to be free and fair is the;
(A) existence of dependent electoral commission
(B) adoption of a flexible constitution
(C) opportunity for people to vote twice
(D) registration of eligible voters

16. The body responsible for conducting and supervising elections in West African countries is called
(A) ombudsman
(B) electoral commission
(C) election observers
(D) constituent assembly

17. Which of the following is not a problem of an electoral commission in West Africa?
(A) Electoral malpractices
(B) inadequate personnel
(C) inadequate funds
(D) All of the above

18. Which of the following is an obligation of a citizen?
(A) Arresting offenders
(B) Voting at elections 
(C) Prosecuting offenders

(D) Adjudicating cases.

19. Countries adopt Universal Adult suffrage for the following reasons Except;
(A) It is democratic
(B) Interest of the people is protected
(C) masses participate
(D) It encourages rigging

20. The geographical units into which a country is divided for the purpose of election are called;
(A) States
(B) Constituencies
(C) Following areas
(D) Country Councils.

21. Which of the following functions is performed by the electoral commission?
(A) Distribution of party membership cards
(B) presenting parties manifestoes
(C) creation of polling units
(D) conducting oath of office for elected president.

22. These are the electoral officers found in a pooling booth Except
(A) Presiding officer
(B) Orderly
(C) Flag bearer
(D) Pooling Clerk

23. A major advantage of secret ballot system of voting is that;
(A) it is faster than other system
(B) it ensures the anonymity of the voter
(C) it extends the franchise to all colts
(D) nobody can be prevented from voting

24. The 'first-past-the-post system of voting is also called
(A) second ballot system
(B) proportional representation
(C) second majority system
(D) alternative vote system

25. Which of the following is not a form of proportional representation?
(A) Alternative vote
(B) Second Ballot
(C) List system
(D) Plurality system

26. The process by which voters may remove a public officer before the end of his term of office is called;
(A) gerrymandering
(B) recall
(C) by election
(D) referendum 
27. The term winner-takes-all can be associated with;
(A) Second ballot system
(B) Representative government
(C) First-past-the-post system
(D) Proportional representation

28. The process of depriving persons of the right of voting is called;
(A) enfranchisement
(B) disqualification dismissal
(C) prohibition
(D) disenfranchisement

29. Where no absolute majority is obtained in the first round of elections, the most viable option is the;
(A) Second ballot withdrawal
(B) Bye-election
(C) Second ballot
(D) Proportional representation

30. Which of this is not a method of election?
(A) Simple majority
(B) Proportional representation
(C) Absolute majority
(D) plurality system

31. A popular form of proportional representation is
(A) Single transferable vote
(B) Communal Representation
(C) The alternative
(D) Electoral college

32. Any type of restricted franchise is a violation of the principle of;
(A) Constitutionalism
(B) Sovereignty
(C) Political equality
(D) Popular election

33. The process by which people vote to elect their representatives is called;
(A) Disenfranchisement
(B) Electoral system
(C) Franchise
(D)Electoral college

34. The electoral officer charged with the responsibility of announcing election results is the ;
(A) Political officer
(B) Resident electoral commission
(C) Supervisory presiding officer
(D) Returning officer

35. To make elections hitch-free and fair, the electoral commission must be;

(A) able to punish electoral offenders 
(B) given a spacious office accommodation

(C) ready to help the government

(D) independent of the executive.

36. One of these is not a feature of free and fair election;
(A) Registration of voters
(B) Issuance of voters card
(C) Lobbying of voters
(D) Display of voters register

37. The body responsible for the conduct of election in a country is called;
(A) Electoral committee
(B) Electoral ward
(C) Electoral party
(D) Electoral Commission

38. An election held when none of the candidates wins the election by absolute majority in a general election is known as
(A) Run-off Election
(B) Second Election
(C) Plebiscite
(D) Election rigging

39. A system in which a candidate with the highest number of votes is declared a winner in an election is called
(A) Absolute system
(B) Proportional representation
(C) Second ballot
(D) Simple majority

40. All these are not the meaning of free and fair election Except
(A) rigging of election
(B) Elections conducted following election rules
(C) Snatching of the ballot box
(D) Burning of election materials

41. These stages are involved in organizing free and fair election Except
(A) Delimitation of constituencies
(B) Registration of voters
(C) Registration of underage voters
(D) revision of voters card

42. Forms of electoral malpractice include all but;
(A) Stealing of election materials
(B) Rigging of election
(C) Mutilation of election results
(D) Announcing the election results

43. The consequences of electoral malpractice include;
(A) Loss of lives
(B) Apathy 
(C) Corrupt leadership

(D) All of the above

44. Which one of these countries practices second ballot system?
(A) Ghana
(B) Liberia
(C) France
(D) All of the above

45. The purpose of a free and fair election is to;
(A) allow people to participate in choosing their leaders
(B) Provide basic amenities for the electorate
(C) declare election results
(D) Buy the electorates' vote

46. Free and Fair election can be achieved through;
(A.) Secret balloting
(B). Rigging
(C.) Plebiscite
(D) Violence

47. The demerits of an electoral college is that;
(A) Wrong candidate nay be chosen
(B) People's right of choice is denied
(C) it encourages bribery and corruption
(D) All of the above

48. Primary election is an election held by;
(A) President
(B) Governor
(C) Political Parties
(D) INEC

49. The process where the electorates vote for the representatives who in turn vote on their behalf is called;
(A) a rigged election
(B) an unfair election
(C) an indirect election
(D) An unpopular election

50. An election in which all the electorates appoint their representative is known as;
(A) Free and fair Election
(B) Direct election
(C) By-election
(D) Indirect Election

\section{Copyrights}

Copyright for this article is retained by the author(s), with first publication rights granted to the journal.

This is an open-access article distributed under the terms and conditions of the Creative Commons Attribution license (http://creativecommons.org/licenses/by/4.0/). 